\title{
Soil respiration and its role in Russia's terrestrial C flux balance for the Kyoto baseline year
}

\author{
By VLADIMIR STOLBOVOI*, International Institute for Applied Systems Analysis (IIASA), Schlossplatz 1, \\ A-2361 Laxenburg, Austria
}

(Manuscript received 30 January 2002; in final form 24 September 2002)

\begin{abstract}
This study introduces a transparent, operational model of estimating soil respiration (SR) to meet the requirements of the Kyoto Protocol of the United Nation Framework Convention on Climate Change within a framework of full carbon accounting (Nilsson et al., 2000). By applying this model, we are able to define SR for the Kyoto 1990 baseline year for Russia (3200 Tg C), and establish soil emission thresholds for any spatial units, e.g. vegetation zones and land-use patterns. This model is built upon a fundamental biogeochemical cycle and provides a scientific basis for carbon management. SR comprised about $74 \%$ of the photosynthetically assimilated carbon in 1990, with the remainder accounted for in several areas. The carbon flux balance is, therefore, found to be closed for Russia. Our findings suggest that incomplete accounting is the reason for missing carbon globally.
\end{abstract}

\section{Introduction}

Soil respiration (SR) is the major link through which photosynthetically assimilated carbon $(\mathrm{C})$ returns to the atmosphere in the natural biospheric $\mathrm{C}$ cycle. Annual SR amounts globally to about $10 \%$ of the atmospheric C pool (Raich and Potter, 1995). Nevertheless, SR is the subject of intensive debate, and basic statements can be rather controversial. SR's contribution to biogeochemical $\mathrm{C}$ turnover remains an unsolved mystery. Some authors report that SR exceeds net primary production (Raich and Schlesinger, 1992), thereby supporting the opinion that boreal ecosystems of the northern hemisphere are a net carbon dioxide source (Oechel et al., 1993; Zimov et al., 1996). This conclusion indicates an alarming degradation of terrestrial biomass, which means a shortage of the earth's major source of energy. This deterioration worsens once other biogeochemical $\mathrm{C}$ fluxes that drain $\mathrm{C}$ of terrestrial ecosystems are factored in, e.g. biomass consumption and disturbances (Nilsson et al., 2000),

\footnotetext{
*e-mail: stolbov@iiasa.ac.at
}

water transport and deep leaching of soluble organic substances, etc. (Dyakonova, 1972; Romankevitch and Vetrov, 2001). A more accurate estimate of the status of the biomass can clearly be derived from an analysis of the net ecosystem carbon balance. This method is a measure of the fluxes' reliability, and is essential in understanding real trends in the alteration of $\mathrm{C}$ pools. Unfortunately, even at the regional scale, all studies utilize different methods and stem from different sources, thereby lacking spatial and terminological consistency. This makes it difficult to incorporate $\mathrm{C}$ fluxes of a different nature into a holistic picture of the terrestrial $\mathrm{C}$ flux balance. The lack of a global $\mathrm{C}$ balance is associated with missing $\mathrm{C}$, which continues to be debated (Myneni et al., 2001).

It is widely thought that SR follows a seasonal rhythm (Mina, 1957; Makarov, 1993; 1988; Raich and Schlesinger, 1992; Raich and Potter, 1995; Kudeyarov et al., 1996). Studies have found low temperature to be a major factor limiting biological activity in soils (Grishina, 1986; Bazilevitch and Rodin, 1971; Bazilevitch, 1993; Hobbie et al., 2000). In-depth observation of soil emissions during the course of a year concludes that SR is negligible in the cold season in 
Russia (Kudeyarov et al., 1996). Since the 1990s, investigations into SR have been intensified considerably in Siberia, the Far East and Alaska. However, the findings of these investigations are controversial, since some of them record SR during the cold (winter) season (Zimov et al., 1996; Zamolodchikov and Karelin, 1998; Oechel et al., 1997) and some do not record emissions during the cold season (Fedorov-Davidov and Gilichinski, 1993; Fedorov-Davidov, 1998). This case indicates region-specific phenomena. The discovery of an ecological niche and a geographical area of winter SR would seem to be important to gain an understanding of the mechanisms and factors driving it.

The Kyoto Protocol of the United Nation Framework Convention on Climate Change (UNFCCC, 1998) focuses on the practical applications of SR. This development brings new problems to be solved and opens up new research dimensions. Examples of such problems include how to make use of temporally heterogeneous databases to define SR for a particular year, e.g. the Kyoto 1990 baseline year, and how to design spatial accounting units for SR. Traditional studies measure SR either through natural vegetation biomes or through soils (Raich and Schlesinger, 1992; Makarov, 1988; Kudeyarov et al., 1996). Neither of these approaches meets the protocol's requirement to account for emission by land-use and land-cover patterns. Clearly, practical applications need technologically sound solutions, which requires serious revision of the current research basis, development of new standards, introduction of new sampling methods, etc.

This paper attempts to address some of the topics mentioned above. The specific objectives of the study are: (1) to contribute to the development of a model for estimating SR specifically within the framework of the full carbon accounting method; (2) to present a transparent estimate of SR for the 1990 baseline year for Russia; and (3) to assess the role of SR in the terrestrial biogeochemical $\mathrm{C}$ flux balance.

\section{Approach}

The study forms part of the full carbon account (FCA) of Russia (Nilsson et al., 2000) [note that the IPCC guidelines (IPCC, 1997) suggest partial greenhouse gas accounting, which is centered on anthropogenically driven emissions and aimed at unifying accounting and national reporting]. The FCA considers SR among other ecosystem carbon (C) fluxes. This approach allows for a distinction between balances of spatially and temporary consistent $\mathrm{C}$ fluxes, which is a scientific basis for regional $\mathrm{C}$ management. Major $\mathrm{C}$ fluxes are: (a) uptake from the atmosphere, which is mainly net primary production (NPP); (b) efflux into the atmosphere through $\mathrm{SR}$; (c) $\mathrm{CO}_{2}$ release from biomass consumption and vegetation disturbances; (d) absorption by soils; and (e) translocation into the hydrosphere and lithosphere. Data on soil emissions derive from several publications, of which Kudeyarov et al. (1996) is the main source. By means of a Geographic Information System (GIS), the emission rates have been associated with soil polygons and analyzed. All spatially explicit data relevant to the study are available on the CD-ROM "Land Resources of Russia" (Stolbovoi and McCallum, 2002).

Total escape of $\mathrm{CO}_{2}$ from soil $\left(\mathrm{SR}_{\mathrm{T}}\right)$ for a region is a sum of emissions from all soils. This notion is described by the equation:

$\mathrm{SR}_{\mathrm{T}}=\sum_{i=1}^{n} S_{i} A_{i} \operatorname{DSR}_{i} N_{i} k_{T^{\circ} \mathrm{C}}$,

where $S_{i}$ is a soil of type $i$, belonging to the range (spectrum) of soils occurring in the region and varying from $i=1$ to $n ; A_{i}$ is the area of soil $i$; $\mathrm{DSR}_{i}$ is the daily emission for soil $i$; $N_{i}$ is the number of emission days for soil $i$; and $k_{T}{ }^{\circ} \mathrm{C}$ is a coefficient correcting emission intensity on mean daily temperature.

Obviously $\mathrm{SR}_{\mathrm{T}}$ comprises both heterotrophic respiration of micro-organisms $\left(\mathrm{SR}_{\mathrm{H}}\right)$, which includes decomposition of organic residues and mineralization of humus substances, and autotrophic respiration $\left(\mathrm{SR}_{\mathrm{A}}\right)$, which represents production of $\mathrm{CO}_{2}$ associated with root biomass growth. The latter should be ignored when the net ecosystem $\mathrm{C}$ flux balance is considered.

The association of $\mathrm{SR}_{\mathrm{H}}$ with any other spatial landcover unit (LAU), e.g. vegetation zone, land-use pattern, etc., is provided by means of overlaying GIS maps. This procedure operates as follows:

$\mathrm{LAU}_{j} \cap S_{m}$,

where $\mathrm{LAU}_{j}$ is a specific spatial land-account unit $j$, and $S_{m}$ is a spectrum of soils occurring in $\mathrm{LAU}_{j}$. Under these conditions the $\mathrm{SR}_{\mathrm{T}}$ for $\mathrm{LAU}_{j}$ is described by eq. (1).

The net ecosystem C flux balance (NCFB) is derived from the equation:

$$
\begin{aligned}
\mathrm{NCFB}= & \mathrm{NPP}-\left(\mathrm{SR}_{\mathrm{H}}+\mathrm{CF}_{\text {soil }}+\mathrm{CF}_{\text {Litho }}\right. \\
& \left.+\mathrm{CF}_{\text {Hydro }}+\mathrm{BCD}\right)
\end{aligned}
$$


where NPP is net primary production; $\mathrm{SR}_{\mathrm{H}}$ is defined above; $\mathrm{CF}_{\text {soil }}$ is $\mathrm{C}$ absorption by soils; $\mathrm{CF}_{\mathrm{Litho}}$ is a $\mathrm{C}$ flux into the lithosphere; $\mathrm{CF}_{\text {Hydro }}$ is a $\mathrm{C}$ flux into the hydrosphere; and $\mathrm{BCD}$ is $\mathrm{C}$ fluxes associated with biomass consumption and vegetation disturbances.

The NCFB is found to be positive and the ecosystem is a sink of $\mathrm{C}$ if the amount of $\mathrm{C}$ input into the ecosystem (NPP) exceeds all C fluxes out of the ecosystem.

\section{Soil emission factors}

Determinants of SR are well known from numerous publications (Mina, 1957; Singh and Gupta, 1977; Grishina, 1986; Makarov, 1993). The kinetics of SR is driven by the microbiological decay of organic residues in soils and the emissions from biochemical processes associated with underground biomass growth. Other factors, e.g. chemical oxidation of organic matter, have only minor significance and can be ignored. Both decay of organic matter and root respiration are highly variable in space and time depending on soil characteristics (acidity, texture, water content, aeration, etc.) and other emission factors (climate, organic input into soil, etc.).

Traditionally, diversity of soil parameters is unified by soil classification. This study is based on an analysis of 164 soil classes. The latter are aggregated by soil divisions, which are the second-level soil taxon in the soil classification of Russia (Stolbovoi, 2000). Figure 1a illustrates geographical distribution of soil divisions in the country. As can be seen from the figure, the European North, Western and Eastern Siberia and the Far East are occupied by cold and humid soil-forming assemblages. These regions have annual mean negative soil temperatures, which is termed "permafrost" (FAO, 1998). Cold temperature leads to the accumulation of organic mass and concentration of biological activity in the warmer topsoil or even on the soil surface. Plant roots tend also to gather into these layers, which limits the effective depth of intensive $\mathrm{C}$ turnover. Under this condition, the leaching of dissolved organic substances (DOS) becomes a major factor of $\mathrm{C}$ penetration into the deep soil horizons.

Table 1 illustrates the area of the variety of soil divisions in Russia. As can be seen, Al-Fe-Humic ${ }^{1}$ (Podzols) soils occupy 365 million hectares (ha), or

\footnotetext{
${ }^{1}$ The revised FAO (1988) legend names are given in brackets.
}

around $23 \%$ of Russian territory. Gleyzems (Gleysols) cover 250 million ha or $16 \%$, Texture-differentiated (Podzoluvisols, Greyzems) soils occupy 249 million ha or $16 \%$, Metamorphic (Cambisols) soils occupy around 208 million ha or $13 \%$, and Peat (Histosols) soils occupy around 116 million ha or $7 \%$ of the total country area. These five soils cover almost $80 \%$ of the country (European Russia, Western and Eastern Siberia and the Far East) and, as mentioned above, are products of the cold and humid climate. Warm soil formation is limited to the southern part of European Russia and the southern regions of Western and Eastern Siberia (Fig. 1a), e.g. Humic-accumulative (Chernozems, Kastanozems) soils occupy about 164 million ha, or $10 \%$ of the country. Soils of a hot arid climate cover only a small area of Russia, e.g. Alkaline clay-differentiated (Solonetz) soils cover some 12.5 million ha or almost $1 \%$, Low-humic accumulativecalcareous (Calcisols) soils just over 4 million ha or less than 1\%, and Halomorphic (Solonchaks) soils 2 million ha or less than $1 \%$.

SR rates are defined by soil characteristics (Table 1). The highest emission rates are about 12 times greater than the lowest rates. The lowest emission intensity, of $0.2 \mathrm{~g} \mathrm{C} \mathrm{m}^{2} \mathrm{~d}^{-1}$, is observed for those soils with an obvious productivity-limiting characteristic, e.g. shallow effective depth (Lithozems), high toxicity (Halomorphic), high redoxpotential (Gleysols) and extreme cold thermal regime (Cryosols). The highest emission intensity, of $2.4 \mathrm{~g} \mathrm{C} \mathrm{m}^{2} \mathrm{~d}^{-1}$, is recorded for Humicaccumulative soils that are rich in organic input due to a well developed rhizosphere. Emissions ranging from 1.0 to $2.0 \mathrm{~g} \mathrm{C} \mathrm{m}^{2} \mathrm{~d}^{-1}$ characterize the majority of soils in the country. An analysis of this group shows that a combination of soil characteristics drives SR if there is no leading productivity-limiting factor. The spatial variation of limiting factors is wide, e.g. variability of gleyic properties in humid soils or of salinity in the arid soils, which explains the high variation in the emission rates. This finding highlights the importance of developing criteria for the selection of sampling sites.

SR in Russia is about $40-50 \%$ lower than reported globally (Raich and Schlesinger, 1992), which can be attributed to the relatively lower productivity of vegetation in the country (Bazilevitch and Rodin, 1971; Bazilevitch, 1993; Shvidenko et al., 2001). One theory is that the cold climate is a major constraint in the organic decomposition in soils, limiting the productivity of ecosystems in high latitudes (Grishina, 1986; Hobbie et al., 2000). 


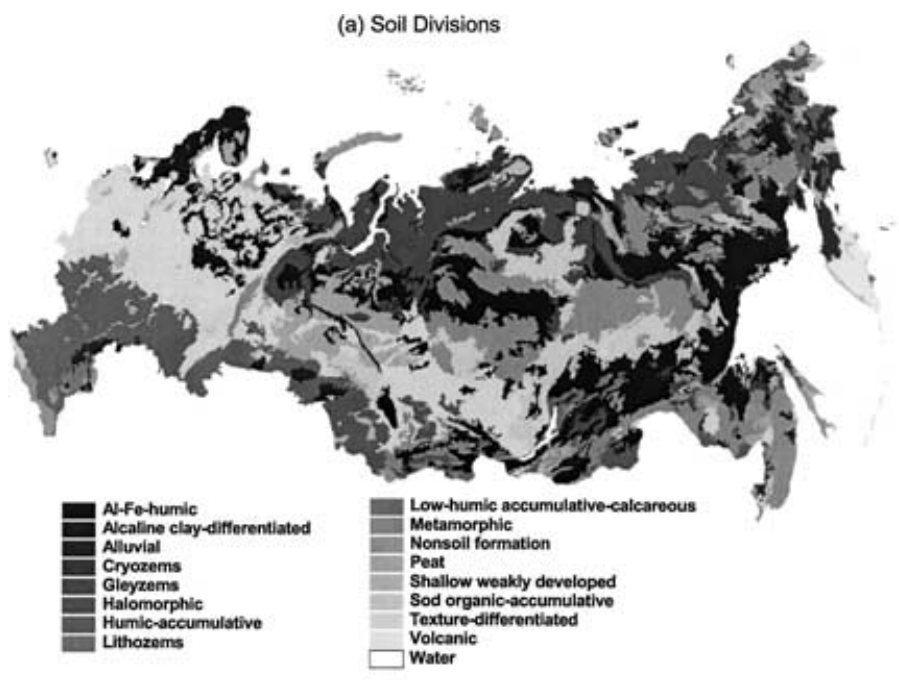

(b) Soil Respiration (C)

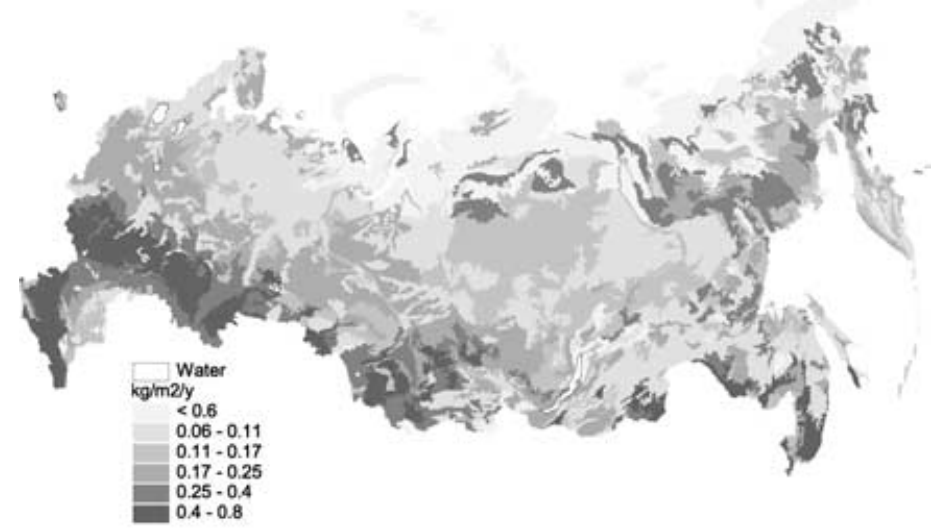

(c) Net Primary Production (C)

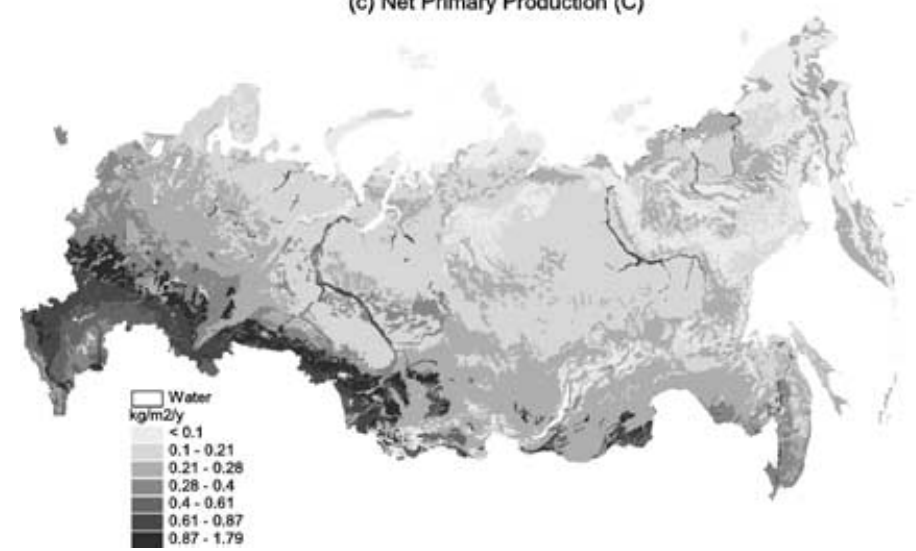

Fig. 1. GIS coverages of: (a) soil divisions, (b) soil respiration and (c) net primary production. Derived from Stolbovoi and McCallum (2002).

Tellus 55B (2003), 2 
Table 1. Aggregated characteristics of soil respiration in Russia

\begin{tabular}{|c|c|c|c|c|c|c|c|c|c|c|}
\hline \multirow[b]{3}{*}{ Soil division } & \multicolumn{2}{|c|}{ Area } & \multirow{3}{*}{$\begin{array}{c}\text { Number }^{\mathrm{b}} \\
\text { of days } \\
\text { above } 0{ }^{\circ} \mathrm{C}\end{array}$} & \multirow{2}{*}{\multicolumn{2}{|c|}{$\begin{array}{l}\text { Total emission, } \\
\qquad \mathrm{g} \mathrm{C} \mathrm{m}^{2} \mathrm{~d}^{-1}\end{array}$}} & \multirow{3}{*}{$\begin{array}{c}\text { Root } \\
\text { emission, } \\
\text { \% of total }\end{array}$} & \multicolumn{4}{|c|}{ Emission } \\
\hline & \multirow{2}{*}{$10^{6} \mathrm{ha}^{\mathrm{a}}$} & \multirow{2}{*}{$\begin{array}{l}\% \text { of } \\
\text { total }\end{array}$} & & & & & \multicolumn{2}{|c|}{ Total, Tg C } & \multicolumn{2}{|c|}{ Heterotrophic for 1990} \\
\hline & & & & Min & Max & & Min & Max & $\mathrm{Tg}$ & $\%$ of total \\
\hline $\begin{array}{l}\text { Alkaline clay- } \\
\text { differentiated }\end{array}$ & 12.5 & 0.7 & 210 & 0.34 & 0.47 & 15 & 9 & 12.4 & 10.6 & 0 \\
\hline Al-Fe-Humic & 364.8 & 23 & 160 & 1.19 & 1.86 & 25 & 650.5 & 1020.3 & 766.2 & 24 \\
\hline Alluvial & 54.2 & 3 & 190 & 0.89 & 1.29 & 20 & 72 & 105 & 84.4 & 3 \\
\hline Cryozems & 9.4 & 1 & 90 & 0.44 & 0.60 & 16 & 3.7 & 5.1 & 4.3 & 0 \\
\hline Gleyzems & 250.0 & 16 & 130 & 0.37 & 0.52 & 15 & 140.3 & 194.2 & 165.3 & 5 \\
\hline Halomorphic & 2.0 & 0 & 200 & 0.39 & 0.53 & 16 & 1.4 & 1.9 & 1.6 & 0 \\
\hline $\begin{array}{l}\text { Humic- } \\
\text { accumulative }\end{array}$ & 163.5 & 10 & 210 & 1.55 & 2.44 & 25 & 533.7 & 837.1 & 628.6 & 20 \\
\hline Lithozems & 7.2 & 0 & 160 & 0.23 & 0.31 & 15 & 2.5 & 3.4 & 2.9 & 0 \\
\hline $\begin{array}{l}\text { Low-humic } \\
\text { accumulative- } \\
\text { calcareous }\end{array}$ & 4.4 & 0 & 260 & 1.38 & 1.91 & 15 & 10.9 & 15.1 & 12.8 & 0 \\
\hline Metamorphic & 207.7 & 13 & 170 & 1.13 & 1.56 & 15 & 350.6 & 485.3 & 413 & 13 \\
\hline Peat & 116.2 & 7 & 150 & 1.43 & 1.97 & 15 & 248.4 & 343.8 & 292.6 & 9 \\
\hline $\begin{array}{c}\text { Shallow weakly } \\
\text { developed }\end{array}$ & 34.5 & 2 & 150 & 0.40 & 0.55 & 15 & 20.6 & 28.5 & 24.3 & 1 \\
\hline $\begin{array}{l}\text { Sod organic- } \\
\text { accumulative }\end{array}$ & 92.4 & 6 & 180 & 0.98 & 1.35 & 15 & 135.5 & 187.6 & 159.6 & 5 \\
\hline $\begin{array}{l}\text { Texture- } \\
\text { differentiated }\end{array}$ & 248.7 & 16 & 190 & 1.00 & 1.47 & 20 & 521.3 & 766.7 & 614.1 & 19 \\
\hline Volcanic & 14.5 & 1 & 160 & 0.67 & 0.92 & 15 & 14.5 & 20 & 17 & 1 \\
\hline Total & 1582 & 100 & & & & 21 & 2714.9 & 4026.4 & 3194.1 & 100 \\
\hline
\end{tabular}

${ }^{\mathrm{a}}$ GIS-derived values. ${ }^{\mathrm{b}}$ Area-weighted average values of emission with temperature $>0{ }^{\circ} \mathrm{C}$.

SR varies annually by about $30 \%$, which is $\pm 15 \%$ if deviations from the mean value are considered (Table 1). This deviation corresponds closely to deviations recorded by global and national studies (Raich and Schlesinger, 1992; Kudeyarov et al., 1996). It is logical to conclude that soil-specific annual fluctuations of SR are primarily the result of a variation in weather conditions from one year to the next.

The intensity of daily SR is functionally dependent on the daily mean temperature (Kudeyarov, 1998), which refers to $k_{T^{\circ} \mathrm{C}}$ in eq. (1). SR reaches only $75 \%$ of the mean summer emission rate when the daily mean temperature falls below $5^{\circ} \mathrm{C}$. The emission rate rapidly decreases when the temperature drops below $0{ }^{\circ} \mathrm{C}$. Table 2 shows a seasonal dynamic of soil emissions for the tundra and taiga zones of Russia. As can be seen from the table, SR from tundra soils in the winter is negligible, and emission practically stops when the soils are frozen. SR from forest soils in the winter is around $5 \%$ of the mean summer rate. By summing emissions of spring, summer and autumn, one may calculate that winter emission contributes about $2-3 \%$ to the annual emission rate. However, in-depth discussion of the magnitude of winter SR can be found in Kudeyarov et al. (1996). The conclusion here is that winter emission makes up around $1-2 \%$ of the annual

Table 2. Soil emissions for tundra and forest (\% of the mean summer emission)

\begin{tabular}{lccccc}
\hline Zone (Source) & Area, $10^{6}$ ha & $\begin{array}{c}\text { Winter, } \\
\text { Dec-Feb }\end{array}$ & $\begin{array}{c}\text { Spring, } \\
\text { Mar-May }\end{array}$ & $\begin{array}{c}\text { Summer, } \\
\text { Jun-Aug }\end{array}$ & $\begin{array}{c}\text { Autumn, } \\
\text { Sep-Nov }\end{array}$ \\
\hline $\begin{array}{l}\text { Tundra } \\
\text { (Fedorov-Davidov and Gilichnski, 1993) }\end{array}$ & 266 & $<1.0$ & n.a. & 100.0 & 1.0 \\
\begin{tabular}{l} 
Forest (Kudeyarov, 1998) \\
\hline
\end{tabular} & 1278 & 5.1 & 53.1 & 109.5 & 67.1 \\
\hline
\end{tabular}


emission rate, which is a reason why the majority of field measurements of SR carried out by research stations in Russia are limited to the warm season.

Some authors found rather intensive winter soil emissions (Zimov et al., 1996; Zamolodchikov and Karelin, 1998). Several mechanisms were thought to be behind the high winter emission rates, e.g. ventilation of $\mathrm{CO}_{2}$ produced in the summer, activity of psychrophillic microbes adapted to cold temperature, among others. However, studies have concluded that the diffusion of $\mathrm{CO}_{2}$ produced in the summer does not correspond to the amount of emitted gas (FedorovDavidov, 1998), and that psychrophilic bacteria are unable to compensate for the general deterioration of intensity of microbiotic processes in frozen soils (Spirina and Fedorov-Davidov, 1998). It is also clear that the ecological niche for psychrophills appears where organic residues cannot be utilized during the warm season. The boundary conditions for this niche are indefinite at present. Field observation by FedorovDavidov (1998) in the tundra of the Kolyma Lowland found emissions during soil freezing amounting to $5.6-18.7 \%$ of annual SR for dry and boggy soils, respectively. An emission rate of $0 \%$ is recorded from frozen soils, which makes sense, as $\mathrm{CO}_{2}$ diffusion from massive soils with ice-filled pores should be limited due to the absence of soil air.

Soil solution freezes when the air temperature falls below -4 to $6^{\circ} \mathrm{C}$. This temperature needs to be even lower (up to -8 to $9{ }^{\circ} \mathrm{C}$ ) if the soil has peat topsoil, which has profound thermoinsulation properties
(Vasilievskaya et al., 1986). We calculate that soil needs $15-20 \mathrm{~d}$ from the first day of negative air temperature to freeze completely. During this period, the emission rate is low, contributing possibly $6-10 \%$ to annual SR rates. This could, therefore, be suggested as a correction factor in calculations of winter SR. However, such a correction should be accepted with great reservation.

Climatic thermal regime defines the duration of biological activity in soils. Figure 2 shows the areaweighted mean monthly temperature by Russian soil divisions. The information is derived from an overlay of the climate grid (Leemans and Cramer, 1991) with soil coverage. As can be seen from Fig. 2, all soil divisions record a negative temperature in the winter and a positive one in the summer. This pattern is common for soils of the northern hemisphere. The difference in average temperatures between the coldest Cryozems and the warmest Low-humic accumulative-calcareous soils is about $20{ }^{\circ} \mathrm{C}$. The difference in the summer temperature deviates for most of the soils in Russia by $9-10{ }^{\circ} \mathrm{C}$. This relatively small variation makes it difficult to distinguish a thermal regime for the majority of soils in the country (Fig. 2). Traditionally, soil association with the vegetation zone defines the temperature regime. Figure 2 illustrates that this approach is confusing, as most of the soils might occur under similar temperature conditions. The figure demonstrates a simple way of identifying the number of days with different temperature thresholds for specific soils. This method has been applied in this study.

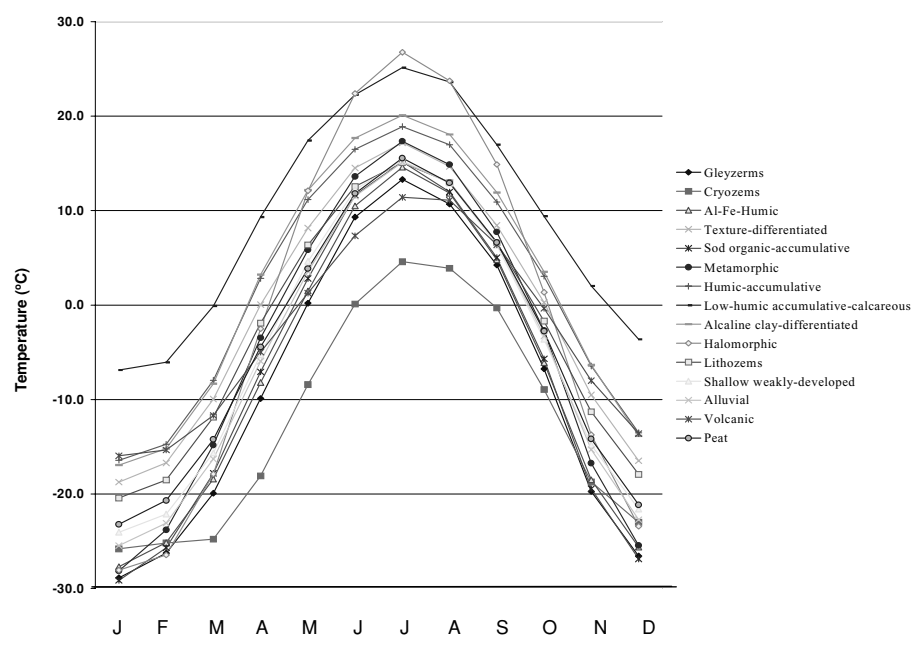

Fig. 2. Aggregated area-weighted mean monthly temperature by soil divisions of Russia to define the length of period above $0{ }^{\circ} \mathrm{C}$.

Tellus 55B (2003), 2 
The average duration of SR (i.e. the number of days above $0{ }^{\circ} \mathrm{C}$ ) for the most frequent soil type in the country is about 130-160 d (Table 1). A small number of soils have emission periods of about $90 \mathrm{~d}$. These soils represent extremely cold Cryosols. The longest emission period duration is around $260 \mathrm{~d}$, and is common for soils of temperate and subtropical climatic zones. Table 1 shows that soils with very different SR intensity can have similar emission period durations. This fact illustrates that the thermal regime plays a much smaller role in SR than does the difference in soil characteristics.

Data on root respiration in Russia are very limited. Nevertheless, a few publications provide values for some of the country's different soils, which roughly account for one-third of total SR (Grishina, 1986; Blagodatski et al., 1993; Fedorov-Davidov, 1998). Data on root respiration vary from 5 to $90 \%$ of total SR. Table 1 illustrates that we assume root respiration to be about $15-25 \%$ of total SR, which is rather conservative. Our assumption stems from the fact that $80 \%$ of the country's soils have annual negative soil temperature and permafrost. As mentioned above, cold temperature is unfavorable for the development of the rhizosphere in the soil. This explains why the majority of soils in Russia do not have a humus horizon (Stolbovoi, 2002). Fine roots tend to concentrate in the upper layer and do not participate in underground organic microbial metabolisms. For this reason, these roots should be accounted together with the non-chlorophyllic fraction of above-ground phytomass.

\section{Soil respiration}

The application of minimum and maximum SR emission rates totals 2715 and $4026 \mathrm{Tg} \mathrm{C}$, respectively (Table 1). This range can be increased by $6-10 \%$ if winter season emissions are included, consequently giving a range of 2878-2987 to 4268-4429 Tg C, respectively. SR shows linear dependence on temperature within these ranges in Russia (Kudeyarov, 1998). This assumption could be applied to define soil emissions for 1990 . Figure 3 illustrates temperature anomalies for 1990. As can be seen, the summer of 1990 was about $0.2{ }^{\circ} \mathrm{C}$ warmer than the summer average for the last $30 \mathrm{yr}$. The spring and autumn of 1990 were warmer by $1.5-2.0^{\circ} \mathrm{C}$, indicating a longer emission period. All of the above allows us to conclude that SR for the 1990 baseline year in Russia should correspond to the upper emission threshold and is around $4026 \mathrm{Tg} \mathrm{C}$, before

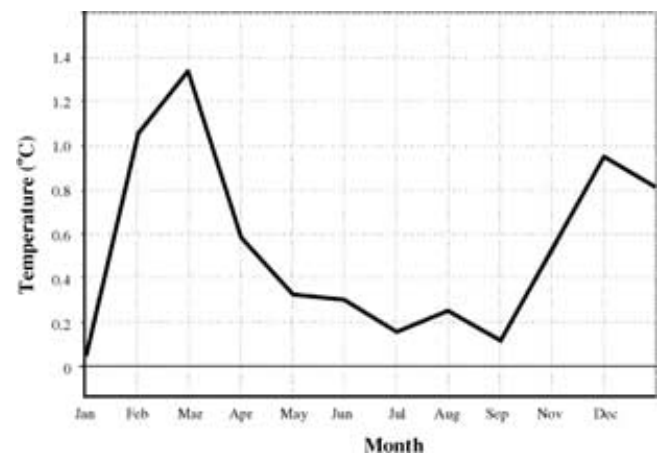

Fig. 3. Temperature anomalies for 1990 (difference compared to 30-yr mean).

correction for winter emissions. Heterotrophic SR for 1990 is estimated at around $3194 \mathrm{Tg} \mathrm{C}$ (Table 1).

Al-Fe-Humic soils contribute about $24 \%$ of the country's heterotrophic SR, which corresponds to their share of the total soil area (Table 1). About $20 \%$ of heterotrophic SR comes from Humic-accumulative soils, and with the highest emission rate indicates a contribution twice as high as their area. In contrast, Gleyzems contribute about $5 \%$ of the total emission to heterotrophic SR, which is about three times less than their area share (16\%). This difference coincides with limited biological activity, low humus content, and an accumulation of under-decomposed raw organic matter in such soils (Stolbovoi, 2002).

Global SR is found to amount to $60000 \mathrm{Tg} \mathrm{C}$ (Lal et al., 1998). Assuming that root respiration comprises one-third of this amount, heterotrophic SR would be about $40000 \mathrm{Tg} \mathrm{C}$. Thus, Russian soils contribute some $7-8 \%$ of the global $\mathrm{CO}_{2}$ emission, which is less than the share of the country's soil area (12\%). This disparity can be explained by unfavorable natural conditions in the country.

Figure $1 \mathrm{~b}$ shows the geographical distribution of SR in Russia. As can be seen from the figure, SR has a rather mosaic spatial pattern that generally follows the geography of biological activity in soils. The European part of Russia demonstrates zonality of SR distribution that is defined by temperature-precipitation ratio (Fig. 1b). The lowest soil emission is found in arctic deserts. Moving south, the emission rate gradually increases, reaching the highest intensity in the steppe zone. Heterotrophic SR decreases in hot semideserts and deserts. Soils of the forest zone in Siberia and the Far East show a rather mosaic picture of SR due to the diversity of soil cover comprising well aerated, 
Table 3. Soil respiration by natural zone in Russia

\begin{tabular}{|c|c|c|c|c|c|c|}
\hline \multirow[b]{2}{*}{ Bioclimate zone } & \multicolumn{2}{|c|}{ Area $^{\mathrm{a}}$} & \multirow{2}{*}{ 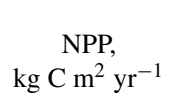 } & \multicolumn{3}{|c|}{ Heterotrophic soil respiration } \\
\hline & $10^{6} \mathrm{ha}$ & $\%$ of total & & $\operatorname{TgC}$ & $\%$ of total & $\mathrm{kg} \mathrm{C} \mathrm{m}^{2} \mathrm{yr}^{-1}$ \\
\hline Arctic deserts & 0.7 & $\ll 1$ & 0.01 & $<1$ & $\ll 1$ & 0.03 \\
\hline Tundra & 266.4 & 16 & 0.12 & 304 & 10 & 0.11 \\
\hline Forest tundra and northern taiga & 232.5 & 14 & 0.18 & 297 & 9 & 0.13 \\
\hline Middle taiga & 682.5 & 42 & 0.26 & 1145 & 36 & 0.17 \\
\hline Southern taiga & 211.2 & 13 & 0.33 & 565 & 18 & 0.27 \\
\hline Temperate forest & 60.2 & 4 & 0.43 & 182 & 6 & 0.30 \\
\hline Steppe & 148.1 & 9 & 0.53 & 582 & 18 & 0.39 \\
\hline Semideserts and deserts & 25.3 & 2 & 0.41 & 65 & 2 & 0.26 \\
\hline Total & 1627.0 & 100 & 0.27 & 3194 & 100 & 0.19 \\
\hline
\end{tabular}

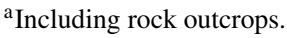

redoximorphic gleyic, gley soil and peat. The highest rate of soil emission is found for cropland. The overall picture shows a good correlation of SR with NPP (Fig. 1c), which is common for Russia and other global regions (Mina, 1957; Bazilevitch and Rodin, 1971; Raich and Schlesinger, 1992). The similarity of all maps is attributed to the geographical distribution of the most productive biomes in the country (Fig. 1).

Table 3 quantitatively summarizes regularities observed on the maps. In addition it shows that the soils of the cold zones emit less than their share of area coverage. Soils of warm zones release more $\mathrm{CO}_{2}$ relative to their area proportion. The principal shift in SR is observed between $\mathrm{SR}$ in the middle taiga $(0.17 \mathrm{~kg} \mathrm{C}$ $\left.\mathrm{m}^{2} \mathrm{yr}^{-1}\right)$ and the southern taiga $\left(0.27 \mathrm{~kg} \mathrm{C} \mathrm{m}^{2} \mathrm{yr}^{-1}\right)$ zones. Soils of the southern taiga have a well developed rhizosphere and are characterized by the formation of humus accumulative horizons that are common also for the warmer soils of the temperate forest and steppe natural zones of Russia. Humus horizons are lacking in the soils of the middle taiga and northward.
Cropland shows the highest rate of soil emission and contributes twice as much as its area share (Table 4). Land-use geography follows the distribution of the highly productive soils. In contrast, pastures yield the lowest emission rate, which is 2.5 times less than their share of the country. We found an intensive $\mathrm{CO}_{2}$ release from wetlands, and less intensive SR from forest and areas of natural grasses and shrubs.

The disparity between emission rates and areas is caused by differences in the soil spectra of vegetation zones and land-use patterns [eq. (2)]. Low SR is recorded in those land-accounting units that are dominated by soils with low biological activity. Disparity between SR and NPP manifests different ecosystem C balances. We suggest that the different $\mathrm{C}$ balances are driven by the current climate warming and a lengthening of the growing season in Russia (Myneni et al., 2001). Supporting this suggestion, we found that a majority of natural ecosystems in Russia are a sink of C at present (Stolbovoi et al., 2001). The biomass increase is widely recognized for forest, grassland and

Table 4. Soil respiration by land-use pattern in Russia

\begin{tabular}{|c|c|c|c|c|c|c|}
\hline \multirow[b]{2}{*}{ Land use } & \multicolumn{2}{|c|}{ Area $^{\mathrm{a}}$} & \multirow{2}{*}{$\begin{array}{c}\mathrm{NPP} \\
\mathrm{kg} \mathrm{C} \mathrm{m}^{2} \mathrm{yr}^{-1}\end{array}$} & \multicolumn{3}{|c|}{ Heterotrophic soil respiration } \\
\hline & $10^{6}$ ha & $\%$ of total & & $\operatorname{TgC}$ & $\%$ of total & 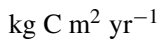 \\
\hline \multicolumn{7}{|c|}{ Agricultural land, of which: } \\
\hline Cropland & 130.3 & 8 & 0.50 & 501 & 16 & 0.38 \\
\hline Pasture & 81.3 & 5 & 0.38 & 75 & 2 & 0.09 \\
\hline Forest & 763.5 & 47 & 0.22 & 1386 & 43 & 0.18 \\
\hline Wetland & 222.0 & 14 & 0.22 & 605 & 19 & 0.27 \\
\hline Grasses and shrubs & 432.5 & 27 & 0.28 & 627 & 20 & 0.12 \\
\hline Total & 1629.6 & 100 & 0.27 & 3194 & 100 & 0.19 \\
\hline
\end{tabular}

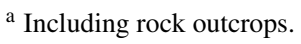

Tellus 55B (2003), 2 
Table 5. Biogeochemicalorganic C fluxes for Russian terrestrial ecosystems in 1990

\begin{tabular}{lrc}
\hline Flux & Tg C & \% of NPP \\
\hline Uptake from atmosphere (NPP) & 4350 & 100 \\
Redistribution: & & \\
Release into atmosphere $\left(\mathrm{CO}_{2}, \mathrm{CH}_{4}\right)$ & 3210 & 74 \\
$\quad$ including human-manageable & 820 & 19 \\
Release into lithosphere and soil & 50 & 1 \\
Release into hydrosphere & 60 & 1 \\
Total redistribution & 4140 & 95 \\
\hline
\end{tabular}

shrubs, swamps with shallow peat, etc. A gradual increase in climate humidity was recorded during the last century (Hulme, 1995), which we propose, along with temperature, to be another factor contributing to the restoration of grasslands in the steppe zone of Russia (Stolbovoi et al., 2001).

\section{Role of soil respiration in the carbon flux balance}

Table 5 illustrates major biogeochemicalorganic $\mathrm{C}$ fluxes for Russia in 1990. These fluxes are related to C uptake from the atmosphere via NPP. The latter includes the production of Russian agricultural and natural terrestrial ecosystems, and is estimated to be about $4350 \mathrm{Tg}$ C for 1990 (Nilsson et al., 2000; Shvidenko et al., 2001).

The share of heterotrophic SR in the total biogeochemical fluxes, including production of methane $\left(\mathrm{CH}_{4}\right)$, is about $74 \%$ (Table 5). As mentioned in the introduction, this finding disagrees with the opinion of Raich and Schlesinger (1992) that SR exceeds NPP. We suggest that this discrepancy originates not only from fragmentary measurements, differences in geographical regions exploited, lack of holistic $\mathrm{C}$ fluxes inventories and disagreement of up-scaling procedures, but also from a confusion of terms, e.g. gross and net production, total and heterotrophic SR, etc. Unfortunately, many publications usually omit terminology definitions and discussions of different methods, which make comparisons difficult.

A considerable portion of biogeochemicalorganic $\mathrm{C}$ fluxes (19\%) is human-manageable (Table 5). Half of the anthropogenic $\mathrm{C}$ fluxes are associated with the annual consumption of biomass and wood harvests. Another half is represented by vegetation disturbances, e.g. anthropogenically initiated wild fires (about $95 \%$ of the total amount). In other words, most of these C fluxes are human-dependent and might vary greatly from year to year. It is important to note that the magnitude of anthropogenic fluxes exceeds the sum of the natural origin fluxes (into soil, lithosphere and hydrosphere). This finding allows us to conclude that management of the $\mathrm{C}$ cycle at a regional level is possible.

About $50 \mathrm{Tg}(1 \%)$ of $\mathrm{C}$ is accumulated by the soil and the lithosphere annually (Table 5). Humification accounts for about $40 \%$ of $\mathrm{C}$, and the rest is absorbed by loose deposits and mainly enters the geological pool, where it participates in the lithogenic processes. We found that most of the $\mathrm{C}$ absorbed by soils comes from DOS transport from above-ground litter. This process explains an intensive $\mathrm{C}$ accumulation in deep soils, e.g. about $20 \%$ of the organic matter of a 2-m soil layer is found in 1-2 $\mathrm{m}$ deep soil in Russia (Stolbovoi, 2002). The $C$ fluxes into the soils and lithosphere make a big hole in the terrestrial $\mathrm{C}$ turnover, removing every $100 \mathrm{yr}$ an amount of $\mathrm{C}$ equal to that produced annually by photosynthesis. Assuming that NPP comprises $10 \%$ of the vegetation $\mathrm{C}$ pool (about $40000 \mathrm{Tg}$ ) in Russia, it is easy to calculate that every $1000 \mathrm{yr}$ all plant-accumulated $\mathrm{C}$ is translocated into the soils and lithosphere. It is important to note that this $\mathrm{C}$ flux has not been investigated intensely, and has not been quantitatively introduced into the global C cycle (Bolin et al., 1979). This confirms the wide recognition that knowledge of the $\mathrm{C}$ transformation and translocation processes in the pedosphere is insufficient and has far to go before meeting the present-day needs (Lal et al., 1998). Clearly, the introduction of soil and lithosphere C fluxes into the global C cycle will substantially contribute to an improved understanding of the cycle and to the development of a more sophisticated accounting method.

The residence time of $\mathrm{C}$ in soil humus is about $1 \times 10-1 \times 10^{3} \mathrm{yr}$ (Orlov and Biryukova, 1998). The residence time of $\mathrm{C}$ delivered to the lithosphere is geochronologically measured, and is practically lost for the biosphere $\mathrm{C}$ turnover. Therefore, both $\mathrm{C}$ fluxes in soils and lithosphere play an important role in the long-term regulation of the global $\mathrm{C}$ cycle.

The C flux into the hydrosphere comprises $1 \%$ of NPP (Table 5) and is associated with $\mathrm{C}$ translocation through underground and surface runoff. Globally, this C flux is reported to be $400 \mathrm{PgC}$ (Lal et al., 1998). At around $15 \%$, Russia's contribution to the global C flux exceeds the country area due to humid climate. This $\mathrm{C}$ is partly involved in the $\mathrm{C}$ turnover within aquatic ecosystems and partly deposited in the sediments and enters the geological pool. 
The net ecosystem C flux balance [eq. (3)] is found to be positive. About $5 \%$ of the photosynthetically assimilated $\mathrm{C}$ has been sequestered by the terrestrial ecosystems of Russia in 1990. An important finding is that SR matches other biogeochemical C fluxes. This conclusion illustrates the high credibility of our estimate and supports an early result of Russian SR assessment (3120 Tg C) made by Kudeyarov et al. (1996). The latest estimate (Kudeyarov, 1998) reports $\mathrm{SR}$ to be about $4400 \mathrm{Tg}$. If we add other biogeochemical C fluxes (Table 5), we come up with terrestrial $\mathrm{C}$ flows of about $5500 \mathrm{Tg}$, which would considerably exceed NPP. This result would suggest that the ecosystems of Russia are a source of $\mathrm{C}$, and that the biota in the country is intensively degraded. Such degradation, however, contradicts well documented data on forest growth, the recovery of grasslands and peat formation, etc. (Shvidenko et al., 2001; Stolbovoi et al., 2001).

The study recognizes that $\mathrm{C}$ flux balance is completed for Russia, which is in agreement with basic matter conservation law (Table 5). No missing $\mathrm{C}$ flux is found. It seems that missing $\mathrm{C}$ sink at the global scale originates from the shortcomings and incompleteness of the accounting method.

\section{Remark on the reliability of the results}

The creditability of SR estimates is a crucial issue for many studies. This notion addresses estimates resulting from model-based approaches in particular. Poor knowledge of processes, insufficiency of experimental data, weak geographical representation, lack of a reliable base for up-scaling, among others, make it clear to understand why SR estimating is considered to be such a complicated process (Nilsson et al., 2000). An assessment of the system's uncertainty includes: (1) the application of modified error propagation theory with a partial use of a priori (personal) probabilities in terms of summarized errors; and (2) a comparison of results received by independent analysis.

The estimate of result validity is subject to the following conditions: (1) the variability of the emission rates for an individual soil is 15\%; (2) the duration of the emission period varies by $5-10 \%$; (3) the soil area error is within 1-2\%; and (4) independent evaluation of experts' judgments involved in the analysis is about $10 \%$. The overall uncertainty of the estimate of total SR flux is about 6-7\% (confidential probability 0.9).

Our estimate of heterotrophic SR (about $3194 \mathrm{Tg}$ C, see Table 1) corresponds very closely with an early assessment (about $3120 \mathrm{Tg} \mathrm{C}$ ) reported by Kudeyarov et al. (1996). It also coincides well with SR estimated for individual biomes, e.g. tundra (Zamolodchikov and Karelin, 1998). This result demonstrates the validity of our model-based calculation.

Finally, combined with other biogeochemical C fluxes, our result is in line with the current understanding of the terrestrial ecosystem C balance of Russia.

\section{Conclusions}

A model for SR estimation in the framework of full carbon accounting is introduced. This model considers SR together with other biogeochemical $\mathrm{C}$ fluxes, and allows for a holistic understanding of the terrestrial $\mathrm{C}$ cycle.

Heterotrophic SR for the Kyoto 1990 baseline year is estimated to be around $3200 \mathrm{Tg}$.

Heterotrophic SR comprises about $74 \%$ of annual terrestrial $\mathrm{C}$ turnover and corresponds with other biogeochemical C fluxes: $19 \%$ of C released into the atmosphere from biomass consumption and vegetation disturbances; $1 \%$ of $\mathrm{C}$ accumulated by soils and leached into the lithosphere; and $1 \%$ of $\mathrm{C}$ transported into the hydrosphere.

The terrestrial ecosystems of Russia were a sink of about $5 \%$ of photosynthetically assimilated C in 1990.

The carbon flux balance has been achieved at the country scale. No missing $\mathrm{C}$ fluxes have been recognized for Russia. This finding suggests that the problem of missing $\mathrm{C}$ originates from incomplete $\mathrm{C}$ accounting globally.

\section{Acknowledgements}

This research is a component of the study "Full Carbon Account for Russia” (Nilsson et al., 2000). M. Gluck provided assistance in the GIS calculations.

\section{REFERENCES}

Bazilevitch, N. I. 1993. Biological productivity of ecosystems of the Northern Eurasia. Nauka. Moscow (in Russian).
Bazilevitch, N. I. and Rodin, L. E. 1971. Production and elements turnover in native and used phytocoenosises. In:

Tellus 55B (2003), 2 
Biological productivity and elements turnover in vegetation communities, Nauka, Leningrad, 5-32 (in Russian).

Blagodatski, S. A., Larionova, A. A. and Evdokimova, I. V. 1993. Contribution of root respiration to $\mathrm{CO}_{2}$ emission from soil. In: Soil respiration, Proceedings of the Institute of Physico-Chemical and Biological Problems of Soil Science of Academy of Science of Russia, Puschino, 26-32 (in Russian).

Bolin, B., Degens, E. T., Kempe, S. and Ketner, P. 1979. The global biogeochemical carbon cycle. In: The global carbon cycle, SCOPE, Vol. 13, 491, John Wiley and Sons, 1-56.

Dyakonova, K. V. 1972. Organic and mineral substances in the lysimeter solution from some soil types and their role in modern soil-forming processes. In: Organic substances of native and managed soils, Nauka, Moscow, 183-223 (in Russian).

FAO 1988. Soil map of the world, revised legend, 1988. World Resources Report, Vol. 60, Food and Agriculture Organization of the United Nations (FAO), Rome, Italy, ISBN 92-5-102622-X.

FAO 1998. World reference base for soil resources. World Soil Resources Report, vol. 84, Food and Agriculture Organization of the United Nations (FAO), Rome, Italy.

Fedorv-Davidov, D. G. 1998. Respiration activity in tundra biocenoses and soils of the Kolyma lowland. Pochvovedenje 3, 291-301 (in Russian).

Fedorov-Davidov, D. G. and Gilichinski, D. A. 1993. Specific of dynamic of soil respiration from permafrost soils. In: Soil respiration, Proceedings of the Institute of PhysicoChemical and Biological Problems of Soil Science of Academy of Science of Russia, Puschino, 76-101 (in Russian).

Grishina, L. A. 1986. Humus formation and humus status of soils. Moscow State University (in Russian).

Hobbie, S. E., Schimel, J. P., Trumbore, S. E. and Randerson, J. R. 2000. Controls over carbon storage and turnover in high-latitude soils. Global Change Biol. 6, Suppl. 1, 196210.

Hulme, M. 1995. Estimating global changes in precipitation. Weather 50, 34-42.

IPCC 1997. Revised 1996 IPCC Guidelines for National Greenhouse Gas Inventories: Reference Manual (Vol. 3) Intergovernmental Panel on Climate Change (IPCC). Available on the Internet: http://www.iea.org/ ipcc/invs1.htm.

Kudeyarov, V. N. 1998. Soil sources of carbon dioxide in Russia. In: Carbon turnover on Russia territory (ed. G. A. Zavarzin). Moscow Branch of SSRC WGD, Ministry of Education of Russia, 163-201 (in Russian).

Kudeyarov, V. N., Hakimov, F. I., Deyeva, N. F., Il'ina, A. A., Kuznetzova, T. V. and Timchenko, A. V. 1996. Evaluation of respiration of Russian soils. Eurasian Soil Sci. 28, 2034.

Lal, R., Kimble, J. and Follet, R. F. 1998. Pedospheric processes and the carbon cycle. In: Soil processes and the carbon cycle (eds. R. Lal, J. M. Kimble, R. F. Follet and B. A. Stemart), Advances in Soil Science, CRC Press LLC, USA, 1-9.
Leemans, R. and Cramer, W. 1991. The IIASA climate database for mean monthly values of temperature, precipitation and cloudiness on terrestrial grid. Research Report RR-91-18, International Institute for Applied Systems Analysis, Laxenburg, Austria.

Makarov, B. N. 1988. Gaseous regime of soil. Agropromizdat, Moscow (in Russian).

Makarov, B. N. 1993. Soil respiration and its role in carbon nutrition of the plants. Agrokhimia 8, 94-104 (in Russian).

Mina, V. N. 1957. Biological activity of forest soils and its dependence on geographical conditions and forest species. Pochvovedenje 10, 73-79 (in Russian).

Myneni, R. B., Dong, J., Tucker, C. J., Kaufmann, R. K., Kauppi, P. E., Liski, J., Zhou, L., Alexeev, V. and Hughes, M. K. 2001. A large carbon sink in the woody biomass of northern forests. Available on the Internet: http://www.pnas.org/cgi/doi/10.1073/pnas. 261555198.

Nilsson, S., Shvidenko, A., Stolbovoi, V., Gluck, M., Jonas, M. and Obersteiner, M. 2000. Full carbon account for Russia. Interim Report IR-00-021, International Institute for Applied Systems Analysis, Laxenburg, Austria.

Oechel, W. C., Hastings, S. J., Vourlitis, G., Jenkins, M. and Grulke, N. 1993. Recent change of Arctic tundra ecosystems from a net carbon dioxide sink to a source. Nature 361, 520-523.

Oechel, W. C., Vourlitis, G. L. and Hastings, S. J. 1997. Cold season $\mathrm{CO}_{2}$ emission from arctic soil. Global Biogeochem. Cycles 11, 163-172.

Orlov, D. S. and Biryukova, O. N. 1998. The stability of soil organic compounds and the emission of greenhouse gases into the atmosphere. Pochvovedenje 7, 783-793 (in Russian).

Raich, J. W. and Potter, C. S. 1995. Global patterns of carbon dioxide emissions from soils. Global Biogeochem. Cycles 9, 23-36.

Raich, J. W. and Schlesinger, W. H. 1992. The global carbon dioxide flux in soil respiration and its relation to vegetation and climate. Tellus 44B, 81-99.

Romankevitch, E. A. and Vetrov, A. A. 2001. Cycle of carbon in the Russian Arctic seas. Nauka, Moscow (in Russian).

Shvidenko, A. Z., Nilsson, S., Stolbovoi, V. S., Rozhkov, V. A. and Gluck, M. 2001. Aggregated estimate of basic parameters of biological production and the carbon budget of Russian terrestrial ecosystems: 2 . Net primary production. Russ. J. Ecol. 2, 71-77.

Singh, J. S. and Gupta, S. R. 1977. Plant decomposition and soil respiration in terrestrial ecosystems. T Bot. Rev. 43, 449-528.

Spirina, E. V. and Fedorov-Davidov, D. G. 1998. Microbiological characterization of cryogenic soils in Kolymskaja lowland. Pochvovedenje 12, 1462-1475 (in Russian).

Stolbovoi, V. 2000. Soils of Russia: correlated with the revised legend of the FAO soil map of the world and world reference base for soil resources. Research Report RR-0013, International Institute for Applied Systems Analysis, Laxenburg, Austria. 
Stolbovoi, V. 2002. Carbon in Russian soils. In: Climatic Change 55, 131-156.

Stolbovoi, V. and McCallum, I. 2002. Land resources of Russia. CD-ROM, International Institute for Applied Systems Analysis, Laxenburg, Austria and the Russian Academy of Sciences, Moscow. Available on the Internet: http://www.iiasa.ac.at/Research/FOR/russia_cd/index. htm.

Stolbovoi, V., Nilsson, S. and Shvidenko, A. 2001. Effect of climate warming on carbon balance of cold ecosystems of Russia. In: Proceedings of the Third International Conference on Cryopedology, University of Copenhagen, Denmark.

UNFCCC 1998. Report of the Conference of the Parties on its Third Session, held in Kyoto from 1 to 11 December
1997. Addendum, Document UNFCCC/CP/1997/7/Add1. Available on the Internet: http://www.unfccc.de.

Vasilievskaya, V. D., Ivanova, V. V. and Bogatirev, L. G. 1986. Soils of the northern part of West Siberia. Thesis, Moscow State University (in Russian).

Zamolodchikov, D. G. and Karelin, D. V. 1998. Biogenic carbon fluxes in Russia tundra. In: Carbon turnover on Russia territory (ed. G. A. Zavarzin). Moscow Branch of SSRC WGD, Ministry of Education of Russia, 146-163 (in Russian).

Zimov, S. A., Davidov, S. P., Voropaev, Y. V., Prosyannikov, S. F., Semiletov, I. P., Chapin, M. C. and Chapin, F. S. 1996. Siberian $\mathrm{CO}_{2}$ efflux in winter as a source and cause of seasonality in atmosphere $\mathrm{CO}_{2}$. Climate Change 33, $111-120$. 